\title{
(2) OPEN ACCESS \\ ABO blood group is a determinant of von Willebrand factor protein levels in human pulmonary endothelial cells
}

\author{
Glenn P Murray, Steven R Post, Ginell R Post
}

Pathology, University of Arkansas for Medical Sciences, Little Rock, Arkansas, USA

\section{Correspondence to} Dr Ginell R Post, Pathology, University of Arkansas for Medical Sciences, Little Rock, AR 72205, USA; gpost@uams.edu

Received 23 August 2019 Revised 10 October 2019 Accepted 14 October 2019 Published Online First 29 October 2019
Check for updates

(C) Author(s) (or their employer(s)) 2020. Re-use permitted under CC BY-NC. No commercial re-use. See rights and permissions. Published by BMJ.

To cite: Murray GP, Post SR, Post GR. J Clin Pathol

2020;73:347-349.

\section{ABSTRACT}

ABO blood group antigens are expressed on von Willebrand factor (VWF) and glycosylation patterns influence circulating VWF levels. The aim of this study was to examine the effect of ABO blood type on tissueassociated VWF protein levels. We selected 35 formalinfixed paraffin-embedded pulmonary tissue blocks obtained at autopsy from decedents who died from pulmonary embolism with known $\mathrm{ABO}$ blood groups ( $\mathrm{O}$, $A, B$ and $A B$ phenotypes), prepared tissue microarrays (TMAs) and stained TMAs with antibodies to VWF and platelet/endothelial cell adhesion marker-1 (PECAM-1) as a marker of endothelial cells. A pixel count scoring algorithm was used to quantify VWF and PECAM-1 staining intensity in pulmonary arterioles in digitised images. Compared with type 0, non-0 individuals have a significantly higher amount of endothelial cell-associated VWF protein expression. VWF protein levels associated with pulmonary vascular endothelial cells is influenced by $\mathrm{ABO}$ antigenic determinants.

\section{INTRODUCTION}

von Willebrand factor (VWF) is a multimeric procoagulant glycoprotein synthesised and secreted by endothelial cells and megakaryocytes. ${ }^{1}$ VWF function in haemostasis is twofold; VWF mediates platelet adhesion to the subendothelium of blood vessels and binds plasma clotting factor VIII (FVIII), protecting FVIII from proteolytic degradation. ${ }^{2}$ The majority of endothelial cell-derived VWF is secreted constitutively; only $5 \%$ of VWF is expressed on the endothelial cell membrane or stored in intracellular Weibel-Palade bodies. ${ }^{2}$ On stimulation with various agonists, such as thrombin and the vasopressin analogue 1-desamino-8-d-arginine vasopressin, mature, glycosylated VWF subunits are secreted from endothelial cells into the circulation with loss of Weibel-Palade bodies. ${ }^{2}$

ABO blood group antigens, $\mathrm{A}, \mathrm{B}$ and $\mathrm{H}$, are expressed on $\mathrm{VWF}^{3}$ and mature subunits of VWF are glycosylated by $\mathrm{ABO} \mathrm{N}$-linked oligosaccharides. ${ }^{4}$ The $\mathrm{ABO}$ gene encodes glycosyltransferases that add carbohydrates residues to the precursor structure or $\mathrm{H}$ antigen. Modified by addition of $\mathrm{N}$-acetyl-D-galactosamine yields type $\mathrm{A}$ antigen, whereas the addition of D-galactose by $\alpha-3$-D-galactosyltransferase produces the type $\mathrm{B}$ antigen. ${ }^{5}$ VWF in individuals with type $\mathrm{AB}$ blood group express both complex carbohydrate antigens, whereas individuals with blood type O lack both glycosyltransferases and express only the
$\mathrm{H}$ antigen. Numerous studies indicate that these $\mathrm{N}$-linked oligosaccharides protect circulating VWF from proteolysis and decrease the rate of clearance from plasma. ${ }^{6-9}$ Based on genotype, individuals homozygous for the $\mathrm{O}$ allele (O blood type or $\mathrm{OO}$ genotype) have the lowest levels of circulating VWF compared with those heterozygous for either $\mathrm{A}$ or $\mathrm{B}$ glycosyltransferase alleles ( $\mathrm{AO}$ or $\mathrm{BO})$; whereas, individuals with both alleles ( $\mathrm{AA}, \mathrm{AB}$ and $\mathrm{BB}$ ) have the highest VWF plasma levels. ${ }^{710}$ Compared with type $\mathrm{O}$, non-O blood type individuals have higher VWF plasma levels and an increased risk for venous thromboembolism. ${ }^{11}$ The effect of $\mathrm{ABO}$ blood group on endothelial cell associated VWF protein levels has not been reported.

The aim of this study was to use immunohistochemistry to investigate VWF protein levels in pulmonary vascular endothelial cells in individuals with known $\mathrm{ABO}$ phenotypes. Using platelet/ endothelial cell adhesion marker-1 (PECAM-1) as marker of endothelial cells, ${ }^{12}$ we compared the intensity of VWF and PECAM-1 protein expression between blood types $\mathrm{O}, \mathrm{A}, \mathrm{B}$ and $\mathrm{AB}$. Similar to plasma VWF concentrations, we found that $\mathrm{ABO}$ blood group is a determinant of endothelial VWF protein levels.

\section{RESULTS}

This Institutional Review Board (IRB) at the University of Tennessee (UTHSC; Memphis, TN, USA) approved this study (IRB \# 17-05683) with a HIPAA waiver of consent. The database at the UTHSC was searched for medical autopsies between 2004 and 2017 in which the primary cause of death was pulmonary embolism. Contributory causes of death included heart disease (atherosclerosis, hypertension or myocardial infarction), recent surgery, infection, malignancy, hemoglobinopathy or coagulopathy. Thirty-five formalin-fixed, paraffinembedded lung tissue blocks from deceased patients with known blood types were procured (13 patients with group O blood type, 13 patients with group A blood type, 6 patients with group B blood type and 3 patients with blood type AB). For this study, pulmonary tissue was used because it is highly vascular and lung tissue blocks were readily available since the cause of death was pulmonary embolism. For each case, pulmonary tissue was selected from grossly normal pulmonary parenchyma to create a tissue microarray (TMA) for each blood group. The TMA blocks were cut at $4 \mu \mathrm{m}$ sections and stained with H\&E, a monoclonal antibody to 


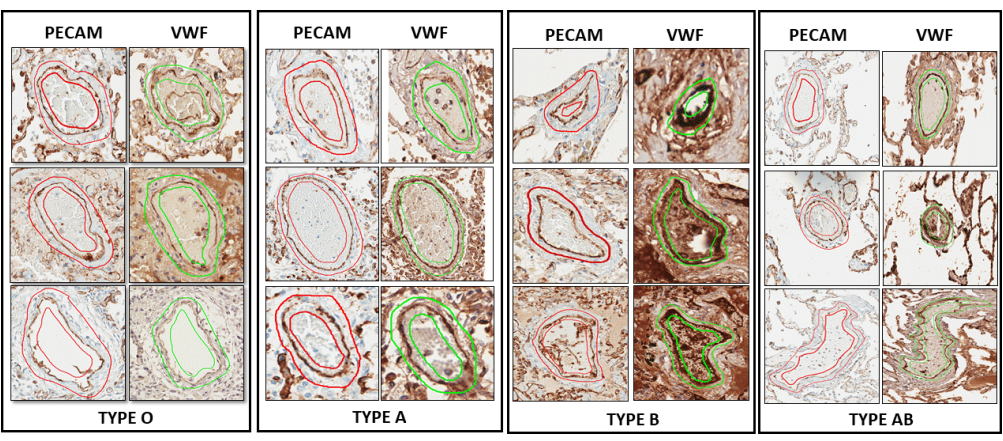

Figure 1 PECAM-1 and VWF immunohistochemical staining in alveolar arterioles in the four blood types $(0, A, B$ and $A B)$. Shown are digitised Aperio scans from representative pulmonary arterioles for each of the four blood groups. PECAM-1 highlights the endothelial cells in each arteriole. VWF in the concordant arteriole shows variable staining intensity in the endothelial cells. The red/green lines demarcate vascular areas used to quantify staining intensity. PECAM-1, platelet/endothelial cell adhesion marker-1; VWF, von Willebrand factor.

VWF (F8/86, Thermo Fisher Scientific) or a monoclonal antibody to PECAM-1 (PECAM-1/CD31; JC70, Roche). For VWF immunohistochemistry, antigen retrieval was performed using $10 \mathrm{mM}$ sodium citrate $(\mathrm{pH} 6.0)$ and microwaved for $10 \mathrm{~min}$. After antigen retrieval, the VWF tissues were blocked using 3\% $\mathrm{H}_{2} \mathrm{O}_{2}$-methanol for $15 \mathrm{~min}$ at room temperature, washed with $\mathrm{ddH}_{2} \mathrm{O}$, phosphate-buffered saline (PBS) and then incubated with the VWF antibody (F8/86) diluted in bovine serum albumin-PBS at $1: 100$ for 1 hour at $37^{\circ} \mathrm{C}$. The VWF-stained TMAs were then washed with PBS-Tween20, incubated with a horseradish peroxidase-conjugated secondary antibody followed by 3,3' diaminobenzidine chromogen. VWF-stained tissue sections were counterstained with haematoxylin. PECAM-1 (CD31) was stained on an automated stainer (Ventana).

Whole slide imagining with Aperio (Leica BioSystems) was performed to digitise the histology and quantify VWF:PECAM staining intensity in uniquely identifiable blood vessels in each blood group. A uniquely identifiable blood vessel was defined as a blood vessel with similar size, shape and spatial location that could be recognised on sequential VWF-stained and PECAMstained TMA sections. To define endothelial cells, positive and negative annotations were created for each vessel; the inner boundary defined the intraluminal/intravascular space and the outer boundary defined the muscle layer (red and green lines, figure 1). A total of 148 pulmonary arterioles were analysed on VWF-stained and PECAM-stained TMAs. The number of vessels analysed in each blood group is shown in table 1 .

A scoring algorithm was created to define strong positive and weak positive pixel thresholds for VWF and PECAM-1 within the annotated area for each blood vessel. The VWF:PECAM intensity ratio was defined as:

\begin{tabular}{llll}
\hline $\begin{array}{l}\text { Table } 1 \\
\text { ABO blood type }\end{array}$ & $\begin{array}{l}\text { Average staining intensity for VWF and PECAM according to } \\
\text { VWerage } \\
\text { staining } \\
\text { intensity }\end{array}$ & $\begin{array}{l}\text { PECAM-1 } \\
\text { average } \\
\text { staining } \\
\text { intensity }\end{array}$ & $\begin{array}{l}\text { VWF:PECAM-1 } \\
\text { intensity ratio }\end{array}$ \\
\hline Blood type & 0.366 & 0.623 & 0.595 \\
\hline Group O ( $\mathrm{n}=46$ vessels) & 0.595 & 0.598 & 1.022 \\
Group A ( $\mathrm{n}=57$ vessels) & 0.697 & 0.567 & 1.320 \\
Group B ( $\mathrm{n}=22$ vessels) & 0.666 & 0.494 & 1.521 \\
\hline Group AB ( $\mathrm{n}=23$ vessels) & &
\end{tabular}

PECAM-1, platelet/endothelial cell adhesion marker-1; VWF, von Willebrand factor.

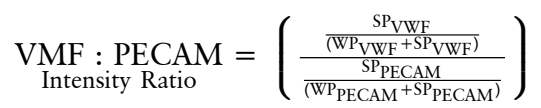

Average PECAM-1 endothelial staining intensity remained relatively constant for each blood type (table 1). Average VWF staining intensity and VWF:PECAM-1 staining intensity ratio were lowest in type $\mathrm{O}$ blood type and highest in type $\mathrm{AB}$ (figure 2 and table 1). Groups were compared by one-way ANOVA followed by Turkey's post hoc test for multiple comparison (figure 2).

\section{DISCUSSION}

VWF protein is a multimeric glycoprotein synthesised and stored in endothelial cells and megakaryocytes. Plasma levels of VWF are influenced by genetic (eg, von Willebrand disease), hormonal (eg, oestrogen) and environmental factors (eg, smoking, acute phase reactant); however, population studies indicate that inherited $\mathrm{ABO}$ blood loci are a major determinant, accounting for $\sim 30 \%$ of total plasma VWF levels. ${ }^{13}$ Plasma levels are lowest in group $\mathrm{O}$ and highest in group $\mathrm{AB}$ individuals. ${ }^{5}{ }^{14}$ Beyond $\mathrm{ABO}$ phenotype, individuals with one $\mathrm{O}$ gene (genotypes $\mathrm{AO}$

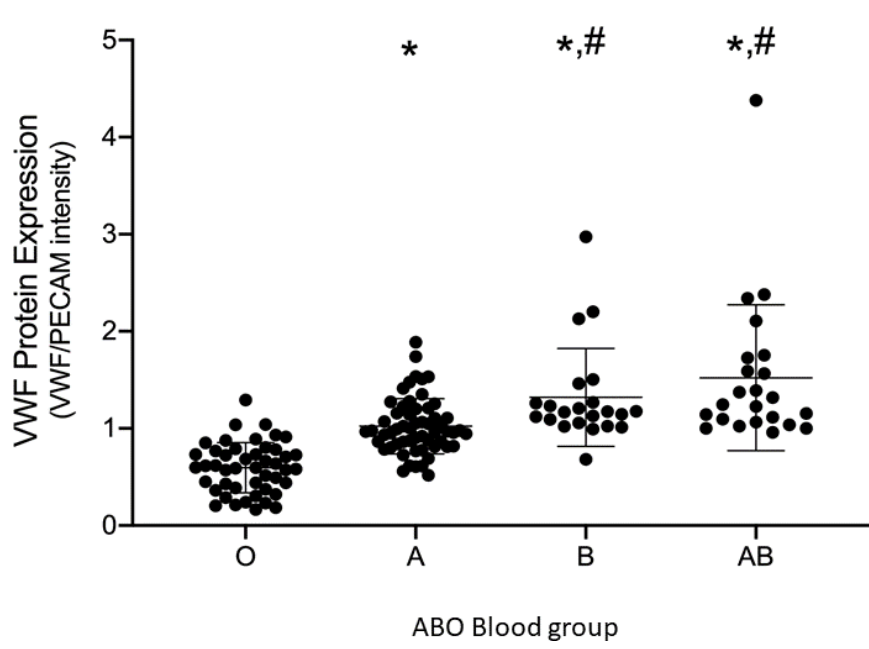

Figure 2 VWF:PECAM staining intensity determined for each blood vessel according to $A B O$ blood type. Each dot represents a uniquely identified blood vessel. Shown are the mean and SEM for each blood group. *Significantly different from type $0(p<0.001)$; \# Significantly different from type $A$ (for type $B p=0.03$, for $A B p<0.001$ ). PECAM, platelet/endothelial cell adhesion marker; VWF, von Willebrand factor. 
and BO) had lower levels of circulating VWF antigen compared with individuals with no $\mathrm{O}$ gene (genotypes $\mathrm{AA}, \mathrm{AB}$ and $\mathrm{BB}$ ). ${ }^{10}$ Lower circulating levels of VWF in blood group $\mathrm{O}$ individuals could be secondary to decreased VWF production/secretion or increased plasma clearance. ${ }^{15} 16$ Previous studies indicate that $\mathrm{ABO}$ antigens influence the rate of VWF proteolysis and hepatic clearance of VWF multimers. ${ }^{6-9}$ Group A and B carbohydrate residues with terminal sialic acid residues, ${ }^{17}$ absent in type $\mathrm{O}$ individuals, protect circulating VWF from proteolytic cleavage by proteases ${ }^{6}$ such as a disintegrin and metalloproteinase with a thrombospondin type 1 motif, member 13 (ADAMTS-13). ${ }^{16} 18$

The influence of ABO blood groups on VWF protein levels in endothelial cells has not been reported. Using an immunohistochemical approach, we systematically investigated VWF protein levels in 148 uniquely identifiable vessels in lung tissue samples obtained from patients who died from pulmonary embolism with known $\mathrm{ABO}$ phenotypes. A limitation of this study is the use of pulmonary tissue collected at autopsy for this analysis. Although the primary cause of death was pulmonary embolism, premortem environmental factors that influence plasma VWF were not identical. In addition, while lung tissue sections used in this study were macroscopically unremarkable, histological sections showed variable postmortem changes, including endothelial cell injury and vascular congestion in a subset of vessels. In addition, histological tissue sectioning can limit the uniformity/ thickness of the imaged vascular wall. To address these issues, we created positive and negative annotations for sequential slides to be as similar in area as possible to minimise secreted/intraluminal VWF and selected vessels with minimal endothelial cell injury as determined by PECAM-1 immunohistochemistry (see figure 1). When normalised to PECAM-1 levels in pulmonary vascular endothelium, VWF protein levels were significantly lower in individuals with type $\mathrm{O}$ blood group compared with non-O blood groups (type A, type $\mathrm{B}$ and type $\mathrm{AB}$ ). The observed VWF protein levels in pulmonary arterioles parallels the relationship observed between $\mathrm{ABO}$ blood groups and circulating plasma VWF levels. ${ }^{14}$ These studies showing that pulmonary endothelial-cell associated VWF protein is lower in individuals with type $\mathrm{O}$ compared with non-O blood groups, suggests that in addition to plasma clearance, $\mathrm{ABO}$ antigens contribute to VWF synthesis and/or secretion in pulmonary arterial endothelium. This finding may account for the lower incidence of thromboembolism among individuals with type O blood. ${ }^{11}$

\section{Handling editor Mary Frances McMullin.}

Contributors All authors included on this paper fulfil the criteria of authorship. There is no one else who fulfils the criteria who has been excluded as an author.

Funding The authors have not declared a specific grant for this research from any funding agency in the public, commercial or not-for-profit sectors.

Competing interests None declared.
Patient consent for publication Not required.

Provenance and peer review Not commissioned; externally peer reviewed.

Open access This is an open access article distributed in accordance with the Creative Commons Attribution Non Commercial (CC BY-NC 4.0) license, which permits others to distribute, remix, adapt, build upon this work non-commercially, and license their derivative works on different terms, provided the original work is properly cited, appropriate credit is given, any changes made indicated, and the use is non-commercial. See: http://creativecommons.org/licenses/by-nc/4.0/.

\section{ORCID iD}

Ginell R Post http://orcid.org/0000-0003-2877-4860

\section{REFERENCES}

1 Ruggeri ZM, Zimmerman TS. The complex multimeric composition of factor VIII/von Willebrand factor. Blood 1981;57:1140-3.

2 Sadler JE. Biochemistry and genetics of von Willebrand factor. Annu Rev Biochem 1998:67:395-424.

3 Sodetz JM, Paulson JC, McKee PA. Carbohydrate composition and identification of blood group $A, B$, and $\mathrm{H}$ oligosaccharide structures on human factor VIII/von Willebrand factor. J Biol Chem 1979;254:10754-60.

4 Matsui T, Titani K, Mizuochi T. Structures of the asparagine-linked oligosaccharide chains of human von Willebrand factor. Occurrence of blood group $A, B$, and $H(0)$ structures. J Biol Chem 1992;267:8723-31.

5 Franchini M, Capra F, Targher G, et al. Relationship between ABO blood group and von Willebrand factor levels: from biology to clinical implications. Thromb J 2007;5:14.

6 Federici AB, Elder JH, De Marco L, et al. Carbohydrate moiety of von Willebrand factor is not necessary for maintaining multimeric structure and ristocetin cofactor activity but protects from proteolytic degradation. J Clin Invest 1984;74:2049-55.

7 O'Donnell J, Boulton FE, Manning RA, et al. Amount of $H$ antigen expressed on circulating von Willebrand factor is modified by $A B O$ blood group genotype and is a major determinant of plasma von Willebrand factor antigen levels. Arterioscler Thromb Vasc Biol 2002;22:335-41.

8 Gallinaro L, Cattini MG, Sztukowska M, et al. A shorter von Willebrand factor survival in 0 blood group subjects explains how $A B O$ determinants influence plasma von Willebrand factor. Blood 2008;111:3540-5.

9 Eikenboom J, Federici AB, Dirven RJ, et al. VWF propeptide and ratios between VWF, VWF propeptide, and FVIII in the characterization of type 1 von Willebrand disease. Blood 2013;121:2336-9.

10 Shima M, Fujimura Y, Nishiyama T, et al. ABO blood group genotype and plasma von Willebrand factor in normal individuals. Vox Sang 1995;68:236-40.

11 Ohira T, Cushman M, Tsai MY, et al. ABO blood group, other risk factors and incidence of venous thromboembolism: the longitudinal investigation of thromboembolism etiology (Lite). J Thromb Haemost 2007;5:1455-61.

12 Pusztaszeri MP, Seelentag W, Bosman FT. Immunohistochemical expression of endothelial markers CD31, CD34, von Willebrand factor, and Fli-1 in normal human tissues. J Histochem Cytochem 2006:54:385-95.

13 Swystun LL, Lillicrap D. Genetic regulation of plasma von Willebrand factor levels in health and disease. J Thromb Haemost 2018;16:2375-90.

14 Gill JC, Endres-Brooks J, Bauer PJ, et al. The effect of ABO blood group on the diagnosis of von Willebrand disease. Blood 1987:69:1691-5.

15 Lenting PJ, VAN Schooten CJM, Denis CV. Clearance mechanisms of von Willebrand factor and factor VIII. J Thromb Haemost 2007;5:1353-60.

16 Bowen DJ. An influence of $A B O$ blood group on the rate of proteolysis of von Willebrand factor by ADAMTS13. J Thromb Haemost 2003;1:33-40.

17 Ward S, O'Sullivan JM, O'Donnell JS. Von Willebrand factor sialylation-A critical regulator of biological function. J Thromb Haemost 2019;17:1018-29.

18 Hayakawa M, Kato S, Matsui T, et al. Blood group antigen A on von Willebrand factor is more protective against ADAMTS13 cleavage than antigens B and H. J Thromb Haemost 2019;17:975-83. 